Концептуально онтологічні моделі підпорядковані певним авторським установкам, за вірогідність автор не несе відповідальності, бо це насамперед художні моделі, які дають можливість відсторонитися від навколишньої дійсності і подивитися на об'єкт власного спостереження збоку, відмежовуючись від нього, тим часом детальніше їх аналізуючи. Екзистенціальне творення онтологічної моделі буття героїв має психологічні параметри характерологічного портрету доби, яка нівелює особистість. Автор завуальовує свою присутність , натомість на передній план виходить онтологічна модель буття людини як модель конфлікту: 1) суб'єкт-об'єкт ( антиномічна опозиція героя до навколишньої дійсності; 2) суб'єкт - суб'єкт( конфлікт між героями, та протистояння зовнішнього і внутрішнього в людини, морального та аморального); 3) суб'єкт- об'єкт-суб'єкт (через конфлікт з дійсністю розпочинається конфлікт 3 іншими героями); 4) об’єкт - суб'єкт (система сама спричинює конфлікт з особистістю).

Таким чином, через змодельований внутрішній стан переживання

конфлікту своїми героями В. Підмогильний віддзеркалює модель всього суспільства, через одну одиницю відображає ціле.

\title{
Література:
}

1. Підмогильний В. Старець. Підмогильний В. Оповідання. Повісті. Романи. Київ, 1991. 802 с.

DOI https://doi.org/10.30525/978-9934-26-110-7-22

\section{ЕКЗИСТЕНЦІЙНА ПРОБЛЕМАТИКА РОМАНУ МАКСА КІДРУКА «ДЕ НЕМАС БОГА»}

\author{
Чонка Т. C. \\ кандидат філологічних наук, \\ доцент кафедри філології (українське відділення) \\ Закарпатський угорський інститут імені Ференца Ракоиі II \\ м. Берегово, Закарпатська область, Украӥна
}

Предметом даного дослідження $\epsilon$ роман молодого сучасного українського письменника Макса Кідрука (1984 р.н., за фахом інженера-енергетика) «Де немає Бога». У статті здійснено інтерпретацію екзистенційної проблематики твору шляхом пообразного аналізу. 
Автор будує свій роман за законами інтелектуальної гри, що визначає шлях його інтерпретації на засадах діалогу „автор - герой - читач». У рецензії члена журі Марти Шокало на книжку Макса Кідрука "Де немає бога", яка увійшла до довгих списків Книги року ВВС-2018, зазначено, що Кідрук пише для масового читача. Не можемо погодитися 3 даним твердженням, адже автор вимагає неабияких інтелектуальних зусиль від читача: чималий відсоток тексту має науково-публіцистичне забарвлення - відомості з авіаційної інженерії, теорії еволюції світу, фахові деталі американського футболу тощо. Проте, незважаючи на емоційне переважання в романі відчуття страху (у цьому цілком погоджуємося 3 Мартою Шокало), уважаємо актуальним і виправданим стиль письменника, головне, щоб сучасний читач прийняв умови цієї інтелектуальної творчої гри і дочитав його до кінця ${ }^{1}$.

Саме екзистенційна проблематика $\epsilon$ «нервом» усього тексту, свідченням чому слугує і сама назва, яка, по суті, $\epsilon$ ключем до розуміння змісту тексту, зокрема i поясненням мотивації вчинків героїв. Символічним $€$ й звернення митця до американського футболу (унесеного до книги рекордів Гіннеса як найінтелектуальнішої групової гри) - матеріалізації шахів, за словами самого автора (див. рекомендовану презентацію). Сучасне суспільство дивним чином керується у своєму житті законами цієї гри: чітко продумовує ходи на шляху до перемоги, не гребуючи жодними хитрощами, адже головне перемогти, бути кращим, а з іншого боку, як звикло виражатися людство, за законами виживання, властивими нібито лише тваринам, - виживає будь-якими шляхами найсильніший. Проте люди настирливо стверджують, що вони є вищими істотами на Землі, адже у них є мораль i релігія. Кідрук, спираючись на наукові праці (список яких він подає у післямові до роману [1, с. 460-463]), зокрема Франса де Вааля «Мораль без релігії. В пошуках людського у приматів» та «Виникнення альтруїзму та доброчинності» Метта Рідлі, спростовує ці постулати: людина здатна втратити всі моральні якості в умовах екстремального виживання, якщо в її серці немає Бога.

Роман не про авіакатастрофу, що сталася через людську недбалість, яка, на перший погляд, видавалася незначними дрібницями, а про людину і ії поведінку у непридатних для життя умовах - Гашербрум VI, південно-західне сідло, щонайменше 5900 метрів над рівнем моря.

${ }^{1}$ Радимо попередньо переглянути повний відеозапис презентації Макс Кідрук "ДЕ НЕМАС БОГА" https://www.youtube.com/watch?v=bOilhXbJWA\&ab_channel=MaxKidruk 
Шестеро уцілілих першого класу: українка Анна Янголь (янгол? -T.Ч.), яка опинилася у салоні першого класу випадково, завдяки співчутливому менеджеру авіакомпанії, (вона летіла до Бангкока, везла 30 тисяч доларів хабаря в українське консульство, щоб врятувати свого сина Артема, який, перебуваючи на заробітках у Москві, погодився перевезти чималу партію наркотиків до Таїланду заради можливості бути з жінкою, яку покохав).

Росіянин, пілот Єгор Парамонов, котрий долею випадку опинився на рейсі 341 пасажиром, щоб замінити у рейсі з Пекіну до Москви свого напарника, у якого померла дружина.

Гравець американської Національної футбольної ліги, 24-річний Лоуренс Грейс - ресивер - мажор, родина якого належала до вищого класу, улюбленець долі. Його батько - полковник Джонатан Грейс із пелюшок привчав сина, «що за Конституцією всі, певна річ, рівні, проте білий усе ж трохи рівніший за чорного» [1, с. 86]. Лоуренс втратив сенс життя, коли Брендон Бартон, «чорношкірий нікчема» із небагатої ciмiі, став на заваді «ЙОГО» перемоги в Супербоулі. Лоуренс навіть не здогадувався, що саме він своїм презирливим ставленням до Бартона, насамперед образливими словами про його покійного батька, додав Брендону сил і наснаги до перемоги. Лоуренс летів до Пекіна на собачі бої, він був переповнений почуттям ненависті і його збуджувала жорстокість собак, які виборювали собі життя, а своїм хазяїнам перемогу.

Найвідоміший політик Баварії Олівер Моргенштерн, який ненавидів політику, мріючи стати письменником, займався нею, бо батько хотів, щоб син продовжив його справу, а після смерті батька через фразу коханої дружини Турід «якщо ти не робиш чиєсь життя кращим, отже, ти марнуєш час» [1, с. 390]. Після безглуздої смерті коханої дружини від золотистого стафілококу у надсучасній клініці Німеччини, коли жодні гроші й здобутки цивілізації не змогли ії врятувати, Олівер втратив сенс життя (навіть думав про самогубство) і став маріонеткою Клауса Волкенхорста, свого радника, який внушав йому, що будь-якими шляхами він має очолити уряд Баварії, щоби робити добро. Проте Олівер усе-таки неодноразово замислювався, чи варто робити добро недобрими шляхами? Помираючи, він згадав слова свого батька: «у житті кожного існує лінія, перетнувши яку, ми вже не можемо змінитися» [1, с. 318] i раптом прозрів: «Раптом ті слова - тільки жалюгідна відмовка, якою Гельмут Моргенштерн прикривав власну зневіреність і небажання змінюватися?» [1, с. 318]. Олівер усвідомив, що це останній його шанс 
перетнути свою лінію антилюдяності - i він рятує життя Лейли, віддавши їй останню воду.

Ізраїльтянка Гелен Горовіц, лікар-трансплантолог, утікала від свого чоловіка - Дені Берковича, який 2006 року переїхав 3 Донецька до Ізраїлю, поплатився за халатність роботою, після чого займався нелегальною поставкою органів для трансплантації із Сирії. Коли Гелен зрозуміла, що відбувається і відмовилася оперувати, він почав ії бити й душити [1, с. 392].

Символічно, що серед героїв є папський кардинал - Дюк Апшоу. Саме його поведінка шокує читача найбільше, адже той, хто має служити Богу й людям, деградує найбільше, стає найстрашнішим у своєму бажанні вижити будь-якою ціною, навіть ціною життя маленької Лейли, яка на початку роману інтуїтивно посміхнулася й заговорила до нього $[1$, c. $75-76]$.

Кардинал Бернард Лоу, який десятиріччями покривав священників-педофілів, став прототипом Дюка. Порожнеча i байдужість прочитувалися в очах кардинала. Замовчування як свідчення байдужості - нехай твориться зло, а я буду осторонь - така життєва позиція $\epsilon$ гріховною для кожної людини. Кардинал з цим жив спокійно. Опинившись у смертельній небезпеці, перед екзистенційним вибором - життя чи смерть, добро чи зло - він егоїстично шукає виправдання своїм нелюдським вчинкам (зіштовхує у прірву Анну, яка намагалася завадити йому вбити Лейлу, щоб теплом ії тіла розтопити у пляшці сніг і здобути життєво необхідну воду). Дюк згадує своє дитинство, рішення віддати життя служінню Богу і сестру Таммі (вона разом зі своїм чоловіком напилися, вдерлися на вечірку, «де два десятки афроамериканців святкували день народження восьмирічного хлопчика. Таммі махала прапором конфедератів і вигукувала расистські гасла, ії чоловік погрожував усім ножем... Апшоу примружився, згадуючи ім’я малого... Брендон Бартон...Таммі отримала 15 , а ії чоловік - 20 років увязнення... Таманта повісилася на вікні своєї камери...» [1, с. 422]. «Потрібно вціліти, хай чого це вартуватиме, бо лише тоді все матиме сенс: і смерть його сестри, i життя Сгорового батька», - знайшов собі виправдання Апшоу [1, с. 426]. Читачеві, на перший погляд, може видатися несправедливим, що автор залишає Дюка живим і практично неушкодженим. «Він повертався до міст із величними церквами та височенними будівлями зі скла, міст, усіяних різноколірними вогнями та просякнутих огидною темрявою, міст таких прекрасних і таких брудних водночас... Повертався туди, де давно немає Бога. Розказувати про те, що таке Бог», - фінальна 
репліка роману звучить як застереження людству. Проте живою залишилася і маленька Лейла - надія на спасіння є.

На літаку знаходилося не менше ніж три десятки дітей різного віку. «Дитячий тиждень... Кожна дитина в супроводі дорослого може полетіти до Пекіна за один долар» $[1$, с. 89$]$ - і всі вони загинули через чиюсь незначну помилку чи, можливо, байдужість. Наш світ $\epsilon$, по суті, таким самим літаком. То чи маємо ми право бути байдужими? Саме це питання, на нашу думку, є найголовнішим, його має задати собі кожен, хто прочитає цей роман. Про це свідчить і один з епіграфів: «Кого хвилює, якщо згасне ще один вогник / У небі, де мільйон зірок? (Linkin Park, пісня «Ще одне світло», 2018). Варто нагадати рефрен цієї пісні: «Мене хвилює».

\title{
Література:
}

1. Макс Кідрук. Де немає Бога. Харків: «Клуб сімейного дозвілля», 2018. $480 \mathrm{c}$.

2. Шокало Марта. Книга року ВВС: Сімнадцять відтінків страху, або У полоні Кідрука.// https://www.bbc.com/ukrainian/features-46208044

DOI https://doi.org/10.30525/978-9934-26-110-7-23

\section{ВИЯВИ КРИЗИ МАСКУЛІННОСТІ В ПОЕТИЧНИХ ТВОРАХ О. ЛЯТУРИНСЬКОЇ}

\author{
Шаболдов О. В. \\ аспірант кафедри украӥнської літератури \\ Д3 «Луганський національний університет імені Тараса Шевченка» \\ м. Старобільськ, Луганська область, Україна
}

Творчість О. Лятуринської $\epsilon$ яскравою складовою поетичного доробку «Празької школи». Ї̈̈ представники загалом поділяли сформульовану О. Ольжичем ідею про необхідність творення нової культури, (О. Ольжич називав іiі націоналістичною). Такою культурою мала бути «позбавлена негативних складників народньої психіки й традиції, героїчно визначена національна культура» [4, с. 144]. О. Ольжич також стверджував, що «провідною ідеєю українського народу від світанку віків $є$ Ідея Слави - тобто безглядна цінність героїчного повнення призначення людини. Це «іскати собі чти, а князю слави» - «Слова о 